\title{
THE USED OF A MEDIUM OF LEARNING SONG FOREIGN LANGUAGE IN LEARNING SPEAK STRANGER IN ELEMENTARY SCHOOL
}

\author{
Amanda Nabila Yusuf \\ Universitas Negeri Malang, Malang, Indonesia \\ amandanabila.1801216@students.um.ac.id
}

\begin{abstract}
In support of an effective and efficient learning process, teachers need to determine how to strategize in appropriate learning. One of the strategies used in foreign language learning is to use learning media, but most teachers do conventional learning without using any learning media. Song is one of the appropriate learning media in language learning especially foreign languages. The purpose of this paper is to show the benefits of using learning media for foreign language songs in foreign language learning at elementary school so the teacher can switch to using effective learning media. The results obtained from the study of this article is that the use of songs on strengthening foreign language skills is recommended because it can help students master 2 of 4 skills, namely listening and speaking. Learners are also more motivated by the use of Song Media in learning because songs create a learning environment that is not boring. Although search websites about songs in learning are declining, but until now it is still sought and quite attractive to the public.
\end{abstract}

Keywords: learning media, foreign language song, foreign language learning

\section{PENGGUNAAN MEDIA PEMBELAJARAN LAGU BAHASA ASING DALAM PEMBELAJARAN BERBAHASA ASING DI SEKOLAH DASAR}

\begin{abstract}
ABSTRAK
Dalam mendukung terjadinya proses pembelajaran yang efektif dan efisien, guru perlu menentukan bagaimana strategi dalam pembelajaran yang sesuai. Salah satu strategi yang cocok digunakan dalam pembelajaran berbahasa asing adalah dengan menggunakan media pembelajaran, namun kebanyakan guru melaksanakan pembelajaran konvensional tanpa menggunakan media pembelajaran apapun. Lagu merupakan salah satu media pembelajaran yang cocok digunakan dalam pembelajaran berbahasa terutama bahasa asing. Maka tujuan dari paper telaah ini adalah untuk menunjukkan manfaat dalam menggunakan media pembelajaran lagu bahasa asing dalam pembelajaran berbahasa asing di jenjang pendidikan Sekolah Dasar sehingga guru dapat mengubah cara belajar dengan mnggunakan media pembelajaran lagu. Hasil yang didapatkan dari kajian artikel ini adalah bahwa penggunaan lagu pada penguatan kemampuan berbahasa asing dianjurkan karena dapat membantu peserta didik menguasai 2 dari 4 keterampilan, yaitu mendengar dan berbicara. Peserta didik juga menjadi lebih termotivasi dengan adanya penggunaan media lagu dalam pembelajaran dikarenakan lagu menciptakan suasana dan lingkungan belajar yang tidak membosankan. Walaupun penelusuran websites mengenai lagu dalam pembelajaran menurun, namun sampai saat ini masih dicari dan lumayan diminati oleh masyarakat.
\end{abstract}

Kata Kunci: media pembelajaran, lagu bahasa asing, pembelajaran berbahasa asing

\begin{tabular}{|c|c|c|}
\hline Submitted & Accepted & Published \\
\hline 15 April 2020 & 06 Mei 2020 & 23 September 2020 \\
\hline
\end{tabular}

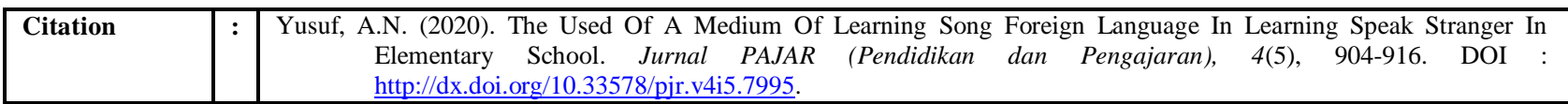

\section{PENDAHULUAN}

Dalam era informasi dan globalisasi ini, pemerintah menyadari pentingnya peran bahasa asing dan sumber daya manusia yang memiliki keandalan berkomunikasi dalam bahasa asing. Peran aktif orang tua sangat diperlukan dalam hal ini, dengan kata lain orang tua pun dituntut untuk mengetahui sedikit tentang bahasa asing agar mereka bisa membeli buku tentang dasar bahasa asing dan mengajarkannya pada anak-anak mereka di rumah meskipun dalam waktu yang singkat agar bahasa asing anak semakin berkembang. Pendidikan untuk anak-anak sebenarnya sangat penting karena keingintahuan yang dimiliki oleh anak-anak sangat tinggi terhadap sesuatu yang belum dapat diketahui. Pendidikan berbahasa sangat penting 
bagi mereka karena melalui bahasa mereka dapat berbicara, bercerita, dan bernyanyi. Hal ini disebabkan karena pembelajaran bahasa untuk anak dapat memudahkan guru dalam memberikan pembelajaran yang berhubungan dengan logika. Selain itu penguasaan terhadap bahasa asing dapat menjadi jembatan bagi suatu bangsa agar dapat berkomunikasi dengan bangsa lain. Di samping itu dari sisi individu, dengan menguasai bahasa asing dapat membuka cakrawala atau wawasan yang luas dan mengembangkan kualitas diri lebih baik. Hal tersebut dikarenakan dengan mempelajari suatu bahasa asing, maka pebelajar juga otomatis akan mempelajari budaya dimana bahasa itu berasal.

Maka dari itu, sudah seharusnya pembelajaran bahasa asing dilakukan sejak anakanak. Dengan dilatihnya peserta didik sejak anakanak, ilmu yang diperoleh ketika masih kanakkanak akan bertahan jauh lebih lama jika dibandingkan dengan ilmu yang diperoleh ketika sudah dewasa. Maka mereka akan terbiasa dengan mengembangkan terus kemampuan yang dimiliki hingga dewasa. Tidak hanya itu, melatih peserta didik sejak kecil memiliki beberapa keunggulan, di antaranya yaitu peserta didik dapat belajar dengan efisien serta mendapatkan ilmu pengetahuan lebih melalui kegiatan-kegiatan pembelajaran yang menarik, khususnya aktivitas yang berhubungan dengan visual, warna, seni peran dan musik dan aktivitas sosial lainnya.

Ada empat keterampilan yang harus dimiliki peserta didik dalam berbahasa asing, antara lain mendengarkan, berbicara, membaca dan menulis (Jazuly, 2016; Nagauleng, 2015). Guru perlu menciptakan suasana yang menarik dalam mencapai empat keterampilan tersebut dengan strategi atau metode di dalam kelas agar peserta didik menikmati dan termotivasi dalam pembelajaran. Inovasi dari strategi ataupun metode pembelajaran tersebut dapat didukung dengan menggunakan media pembelajaran. Dikarenakan proses belajar yang dialami oleh peserta didik tertumpu pada berbagai kegiatan menambah ilmu dan wawasan untuk bekal hidup di masa sekarang dan masa mendatang. Cara bagaimana agar dapat menciptakan situasi belajar yang dapat memungkinkan terjadinya proses pengalaman belajar pada siswa adalah dengan menggerakkan segala sumber belajar dan cara belaajr yang efektif dan efisien, contohnya menggunakan media pembelajaran (Mahnun, 2012). Guru perlu menggunakan media pembelajaran yang inovatif sehingga keempat keterampilan tersebut dapat dimiliki oleh peseta didik sehinga menikmati dan termotivasi dalam pembelajaran. Salah satu media yang dapat membantu peserta didik mencapai empat keterampilan tersebut dalam berbahasa asing yaitu media audio pembelajaran berupa lagu.

Berdasarkan masalah bahwa pembelajaran berbahasa asing perlu dilakukan sejak anak-anak, dan penggunaan media sangat diperlukan maka tujuan dari artikel telaah ini adalah untuk mengetahui lebih dalam penggunaan serta manfaat media audio berupa lagu bahasa asing dalam pembelajaran berbahasa asing.

\section{KAJIAN TEORETIS}

Pada kenyataannya, berbagai fakta mengindikasikan bahwa masih terdapat berbagai kendala di lapangan dalam pelaksanaan pembelajaran yang memadai. Sebagai contoh dalam penelitian Ratminingsih adalah pembelajaran bahasa Inggris yang juga masih kurang diminati oleh peserta didik. Berdasarkan hasil survei yang telah dilakukan dalam penelitian lain (Ratminingsih, 2010) kepada guru-guru bahasa Inggris di SD di Kecamatan Buleleng dan Sukasada hanya mengimplementasikan pembelajaran dengan melafalkan kosakata melalui metode drills dan menjelaskan kosakata bahasa Inggris melalui terjemahan ke dalam bahasa pertama (Ratminingsih, 2010). Dalam wawancara juga dijelaskan bahwa guru-guru di desa tersebut tidak pernah sama sekali menggunakan media pembelajaran inovatif audio (lagu-lagu) dan hanya berpedoman pada buku. Padahal dengan melodi lagu, sangat memudahkan kita untuk mengingat dan memahami kata-kata yang disampaikan di dalam lagu tersebut. Oleh karena itu, dalam pengajaran bahasa asing, terutama dalam pengajaran listening sangat dianjurkan untuk 
memakai lagu-lagu berbahasa asing tersebut sebagai media pembelajaran.

Ostojic (Nagauleng, 2015) menyatakan bahwa musik, terutama lagu, merupakan salah satu ekspresi dasar dari jiwa manusia, dan telah menjadi bagian penting dalam pengajaran bahasa asing. Oleh karena itu lagu bukan hanya sebagai sarana hiburan, tetapi juga sarana pengiriman pesan. Bahkan dengan memperdengarkan peserta didik lagu yang populer membantu peran memori verbal dalam pembelajaran berbahasa asing (Coleman, 2017). Tidak hanya itu, dengan menggunakan lagu populer sebagai media pembelajaran, peserta didik juga dimudahkan dalam memahami grammar bahasa asing. Pernyataan ini didukung oleh Pierce (Nagauleng, 2015) yang menyatakan bahwa penggunaan musik pop dalam pengajaran membawa budaya Inggris ke dalam kelas, sedangkan penggunaan musik hits dapat memberikan motivasi yang kuat bagi siswa yang ingin memahami apa arti lagu dan bahkan bernyanyi bersama.

Penelitian tidak hanya menemukan bahwa musik dapat menguntungkan perkembangan global umum peserta didik, namun juga dapat disugestikan berdasarkan sebuah fakta anak-anak sering menyanyikan kata-kata yang belum dapat mereka ucpakan, mengartikan bahwa musik berperan penting dalam mengembangkan kosakata (Rukholm, 2015). Penggunaan lagu dalam kelas bahasa asing memiliki beberapa pengaruh. Hal ini didukung oleh Lo dan Li (Keskin, 2011) yang menyatakan bahwa lagu dapat mengubah suasana yang monoton di dalam kelas. Cheung (Keskin, 2011) memaparkan bahwa peserta didik lebih mudah mempelajari suatu hal yang mereka pahami lebih dulu, sehingga motivasi mereka akan meningkat jika hal tersebut berhubungan dengan kebudayaan yang populer atau trending dalam kelas. Maka jenis genre musik yang dapat digunakan sebagai media pembelajaran pada pembelajaran bahasa asing adalah lagu pop berbahasa asing yang familiar di telinga siswa. Selain itu juga dapat menggunakan lagu anak-anak bahasa asing yang mudah untuk dipahami oleh anak-anak.

\section{METODE PENELITIAN}

Metode yang digunakan dalam melakukan kajian ini penulis menggunakan pendekatan linguistik. Artikel ini termasuk ke dalam library research, data yang dikumpulkan yaitu dilakukan dengan mengutip dan menganalisis dengan menggunakan analisis pengumpulan data terhadap literatur representatif dan mempunyai masalah yang relevan dengan pembahasan, kemudian diulas dan disimpulkan.

\section{HASIL DAN PEMBAHASAN \\ Media Pembelajaran}

Kata media berasal dari bahasa Latin yaitu "medium" yang diartikan sebagai perantara atau pengantar. Secara umum, artinya adalah segala sesuatu yang dapat menyalurkan informasi dari sumber informasi ke penerima informasi (Mahnun, 2012; Nurseto, 2011). Dari penjelasan umum tersebut, dapat dijelaskan bahwa media berperan penting dalam komunikasi. Pada hakikatnya, proses belajar mengajar merupakan bentuk dari komunikasi, sehingga perantara yang digunakan disebut dengan media pembelajaran.

Media dalam pendidikan adalah sebuah instrumen yang berpengaruh dalam menentukan keberhasilan dari proses belajar mengajar. Dikarenakan sebuah media secara langsung dapat memberikan dinamika tersendiri terhadap peserta didik (Arsyad, 2011). Jika dilihat lebih dalam, media dalam pembelajara hanya dianggap sebagai alat bantu dalam proses maupun kegiatan belajar mengajar. Alat bantu dalam proses maupun kegiatan belajar mengajar dapat berupa alat bantu visual seperti gambar, grafis, bagan, dan lain-lain. Media pembelajaran audio dapat berupa lagu, rekaman, musik dan lain-lain. Serta media audiovisual berupa video.

Pemanfaatan media pembelajaran dapat diklasifikasikan berdasarkan gambar kerucut pengalaman Edgar Dale di bawah ini : 


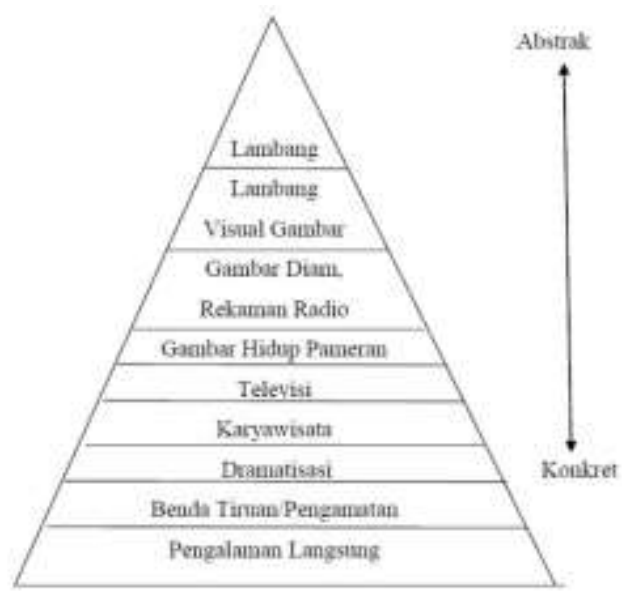

Gambar 1. Kerucut Pengalaman Edgar Dale

Apabila dikaitkan dengan fungsi media pembelajaran, maka ada beberapa hal yang dapat ditekankan pada fungsi media sebagai berikut (Nurseto, 2011) : 1) Sebagai sarana yang dapat membantu untuk menciptakan situasi belajar yang efektif, 2) Sebagai satu dari beberapa komponen pembelajaran yang berkaitan dengan komponen lainnya untuk menciptakan situasi belajar yang diinginkan, 3) Dapat mempercepat jalannya proses pembelajaran, 4) Dapat meningkatkan kualitas dari proses pembelajaran, dan 5) Mengkonkritkan abstrak sehingga dapat meminimalisir penyakit verbalisme.

Memanfaatkan media pembelajaran dapat meningkatkan motivasi belajar, minat dan keinginan dalam belajar peserta didik. Manfaat dari pemanfaatan media dalam proses belajar mengajar, antara lain menurut Sudjana dan Rivai (Nurseto, 2011): 1) Dapat meningkatkan motivasi belajar dikarenakan pengajaran yang lebih menarik perhatian, 2) Makna dari bahan yang diajarkan menjadi lebih jelas dan dapat dipahami peserta didik lebih mudah sehingga memungkinkan terjadinya penguasaan serta pencapaian tujuan pengajaran, 3) Metode pengajaran yang bervariasi tidak hanya komunikasi verbal dengan kata-kata, dan 4) Peserta didik akan banyak melakukan aktifitas dalam belajar seperti melakukan pengamatan, demonstrasi, penerapan dan pemeranan, bukan hanya mendengarkan ceramah saja.
Sedangkan Kemp dan Dayton (Falahudin, 2014) mengidentifikasi manfaat dari media sebagai berikut: 1) Guru dalam menyampaikan materi dapat diseragamkan, 2) Proses pembelajaran menjadi lebih jelas dan menarik, 3) Proses pembelajaran dapat menjadi lebih interaktif, 4) Penggunaan waktu dan tenaga lebih efisien, 5) Hasil belajar peserta didik dapat meningkat, 6) Memungkinkan terjadinya proses pembelajaran yang fleksibel, 7) Peserta didik dapat menumbuhkan sikap positif terhadap materi dan proses pebelajar dengan media, 8) Peran peserta didik menjadi lebih ke arah yang positif, 9) Materi pelajaran yang abstrak dapat menjadi lebih konkrit, 10) Masalah waktu dan tempat dapat teratasi dengan media, dan 11) Keterbatasan indera manusia dapat teratasi. Maka manfaat dari penggunan media pembelajaran lagu adalah memudahkan penyampaian materi seperti pronounciation atau kosakata baru dari guru kepada siswa, sehingga tercipta proses pembelajaran yang efektif dan efisien. Penggunaan media lagu pun dapat meningkatkan hasil belajar peserta didik dalam pembelajaran serta membangkitkan motivasi dan semangat belajar.

Klasifikasi media berdasarkan ciri utamanya, yaitu suara, visual, dan gerak. Apabila dikembangkan lagi, maka terdapat 7 kelompok media, yaitu menurut Rudy Bretz (Mahnun, 2012): 1) Media audio-visual-gerak, 2) Media 
audio-visual-diam, 3) Media audio-semi-gerak, 4) Media visual-gerak, 5) Media visual-diam, 6) Media audio, dan 7) Media cetak. Media yang digunakan adalah media lagu, sehingga termasuk ke dalam kelompok media audio.

\section{Pembelajaran dengan Lagu}

Manusia memiliki bakat dalam segi musik sejak bayi dan pada dasarnya anak-anak suka dengan kegiatan menyanyi menurut Ilari dan Sundara (Subali \& Handayani, 2012). Manusia terutama anak-anak cenderung suka meniru serta menghafalkan lagu dan musik. Hal tersebut dikarenakan musik maupun lagu merupakan hal yang selalu menarik perhatian manusia untuk dibicarakan. Apabila guru menggunakan strategi untuk menggabungkan musik dan lagu yang merupakan hal yang menarik perhatian manusia dengan pembelajaran yang kurang menarik, maka terdapat kemungkinan bahwa peserta didik akan termotivatsi dalam melakukan kegiatan pembelajaran.

Bentuk penggunaan lagu yang dimanfaatkan dalam pembelajaran salah satunya dapat dilihat pada penelitian berikut. Lagu perjuangan dapat dijadikan sebagai inovasi strategi dalam pembelajaran sejarah dalam membangun kesadaran nasionalisme peserta didik. Alasan digunakannya lagu perjuangan adalah dikarenakan lagu tersebut disebut dengan istilah musik fungsional yaitu fungsi sekundernya adalah sebagai media agitasi politik yang berguna untuk membangkitkan semangat perjuangan melawan penindasan (Printina, 2017). Melalui lagu perjuangan, guru dapat mengajarkan kepada peserta didik mengenai cinta tanah air, lingkungan, kesetiakawanan sosial, semangat kebangsaan dan sebagainya. Bahkan, guru dalam menerapkan sebuah strategi pembelajaran, sudah seharusnya mengedepankan lagu-lagu perjuangan sehingga kesadaran nasionalisme akan muncul dalam diri peserta didik (Printina, 2017).

Bukan hanya pada pembelajaran sejarah saja, menggunakan lagu sebagai inovasi pembelajaran juga dapat digunakan pada pembelajaran Pendidikan Kewarganegaraan. Dengan model pembelajaran Snowball Throwing digabungkan dengan lagu anak-anak, maka peserta didik dapat memahami konsep pemahaman yang sulit kepada peserta didik (Lestari, Suniasih, \& Darsana, 2017). Tidak hanya itu saja, penggunaan model snowball throwing dengan lagu anak-anak dapat membuat guru mengetahui sejauh apa pengetahuan dan kemampuan peserta didik pada materi. Hal tersebut dapat membantu peserta didik aktif dalam memperoleh informasi. Peserta didik akan lebih aktif tanpa disadari jika mereka sedang belajar, dengan adanya kreativitas dalam pemanfaatan lagu anak-anak (Lestari et al., 2017). Hasil dari penelitian tersebut adalah, hasil kompetensi pengetahuan peserta didik dalam kelas eksperimen lebih tinggi daripada peserta didik dalam kelas kontrol. Melalui model tersebut, peserta didik dapat menumbuhkan kreativitasnya dalam membuat soal sekaligus menguji daya serap materi yang disampaikan oleh ketua kelompok. Tidak hanya itu saja, model tersebut dapat memotivasi dan membantu peserta didik lebih memahami materi yang diajarkan. Penggunaan media lagu anak-anak dalam mengembangkan kemampuan kosakata dan dapat meningkatkan kemampuan serta ketrampilan untuk mengungkapkan ide dan bahasa secara tepat.

Salah satu bentuk penggunaan media lagu dalam pembelajaran yang lain adalah pada pembelajaran matematika dalam pengajaran ethnomatematika. Berdasarkan penelitian yang telah dilakukan, terdapat hubungan antara lagu atau musik dengan matematika. Ketrampilan menciptakan sebuah lagu sebagai ethnomatematika dalam sebuah pembelajaran matematika sangat mungkin untuk membantu peserta didik dalam memperoleh gambaran secara jelas terhadap konsep kaidah pencacahan, sekaligus memberikan wawasan bahwa matematika secara tidak langsung dipergunakan secara luas dalam berbagai bidang kehidupan (Atmaja, 2014).

Penelitian mengenai penggunaan lagu dalam pembelajaran bahasa asing ada begitu banyak terutama dalam pembelajaran bahasa Inggris. Penggunaan media audio lagu terbukti efektif dalam meningkatkan hasil belajar bahasa Inggris siswa kelas lima Sekolah Dasar. Tidak 
hanya itu, siswa juga memiliki persepsi positif terhadap pemanfaatan media audio berbasis lagu dalam pembelajaran yang terbukti dari hasil kuesioner bahwa semua siswa sangat setuju dengan pemanfataan media pembelajaran lagu yang dapat meningkatkan motivasi belajar mereka (Ratminingsih, 2010). Penelitian yang lain pada pembelajaran yang sama yaitu bahasa Inggris, juga memberikan hasil yang sama. Kegiatan pengajaran kosakata bahasa Inggris memberikan stimulus yang bagus bagi guru dan siswa. Pada awalnya siswa masih merasa janggal memperlajari kosakata bahasa Inggris yang kurang familier dikarenakan pengucapan bahasa Indonesia yang masih sukar bagi mereka. Namun permasalahan tersebut berangsur-angsur semakin berkurang dikarenakan media pembelajaran lagu yang menarik dan ceria yang dapat menarik antusias siswa dalam menyimak materi. Media lagu merupakan salah satu alternatif dalam melaksanakan kegiatan belajar mengajar yang menyenangkan, ceria dan mudah dipahami. Tidak dapat dipungkiri bahwa media lagu berdampak besar dalam mengembangkan kemampuan kosakata bagi anak-anak (Miranti, Engliana, \& Hapsari, 2015).

\section{Pembelajaran Berbahasa Asing}

Bahasa merupakan sebuah alat komunikasi bersistem secara keseluruhan aturan atau pedoman yang ditaati oleh pemakai. Pengajaran dan pembelajaran bahasa asing mengacu artian pada mengajar atau membelajarkan bahasa bukan asalnya di luar lingkungan bahasa tersebut biasa digunakan atau diucapkan (Moeller \& Catalano, 2015). Tidak jarang definisi dari bahasa kedua dengan bahasa asing dianggap berbeda. Sebuah bahasa dikatakan asing jika bahasa tersebut diajarkan secara luar di kelas serta tidak digunakan atau diucapkan di kalangan masyarakat luas di mana bahasa tersebut diajarkan. Belajar bahasa asing dapat membuat seorang individu berkomunikasi secara efektif dan kreatif dan untuk berpartisipasi dalam keadaan nyata melalui kebudayaan yang autentik pada bahasa itu sendiri (Moeller \& Catalano, 2015). Sebuah hal diyakini bahwa bahasa pertama turut campur dalam perolehan bahasa kedua dan bahwa ada sebuah pemindahan dari bahasa pertama ke bahasa kedua yang dapat menyebabkan gangguan. Penelitian telah mengungkapkan bahwa terdapat sedikit korelasi antara aturan yang diajar pada peserta didik dengan pengetahuan mereka yang berkembang akan bahasa kedua.

Konsep dari bahasa nasional menciptakan sebuah perskriptif tata bahasa dan kamus yang garis tengah antara kedua hal tersebut (Dufva, Suni, Aro, \& Salo, 2011). Tidak hanya itu, tata bahasa serta kamus sangat membantu dalam menyokong pandangan pada bahasa. Kemampuan dalam mengatur bahasa lain selama bahasa asing digunakan dapat meningkatkan kemampuan bilingual dari monolingual dikarenakan pengalaman linguistik yang dialami sebelumnya. Selama mendengarkan pidato dalam bahasa yang baru bagi seorang individu, kata-kata dalam bahasa yang diketahui dapat teraktivasi (Bartolotti \& Marian, 2012). Seseorang yang memiliki kemampuan bilingual lebih besar peluangnya dalam menekan kata-kata kompetitor daripada seorang monolingual, yang menyebabkan naiknya kata-kata kompetitor untuk mendukung seorang bilingual dengan pengalaman lebih dalam menghadapi kompetisi.

Terdapat empat keterampilan dasar dalam berbahasa, yaitu mendengarkan, berbicara, membaca dan menulis. Keempat keterampilan tersebut berhubungan satu sama lain berdasarkan 2 paramater, yaitu cara dalam berkomunikasi (lisan atau tulisan) dan arah dalam berkomunikasi (menerima atau menciptakan pesan) (Aydoğan \& Akbarov, 2014). Keterampilan mendengar adalah kemampuan menerima dengan cara lisan. Sedangkan ketrampilan berbicara adalah kemampuan menciptakan pesan dengan cara lisan. Tidak jarang keterampilan berbicara seringkali dihubungkan dengan keterampilan mendengar. Keterampilan membaca merupakan kemampuan menerima dengan cara melalui tulisan. Kemampuan ini berkembang seiring dengan berkembanganya keterampilan mendegarkan dan berbicara. Membaca dapat membantu peserta didik dalam membangun kosakata yang berguna dalam keterampilan mendengarkan. Dan keterampilan yang terakhir yaitu menulis yang 
merupakan kemampuan menciptakan dengan cara melalui tulisan.

Steinberg (Gilakjani \& Sabouri, 2016) mendefinisikan bahwa kemampuan mendengarkan dalam pembelajaran berbahasa adalah kemampuan seseorang dalam menyadari dan mengalokasikan makna lain dalam suatu pesan agar lebih mudah dimengerti. Beberapa kendala yang dihadapai peserta didik dalam kemampuan mendengarkan pembelajaran berbahasa adalah kualitas dari materi yang direkam, perbedaan kebudayaan, aksen, kosakata yang tidak familiar di telinga peserta didik, serta panjang dan kecepatan kemampuan mendengar peserta didik. Sayangnya, kemampuan dalam mendengarkan diabaikan oleh guru dalam pembelajaran berbahasa asing terutama Bahasa Inggris, padahal kemampuan mendengarkan adalah sebuah proses yang kompleks.

Kosakata merupakan bagian esensi dalam pembelajaran berbahasa asing dalam mengartikan kata-kata baru (Alqahtani, 2015). Kosakata sendiri merupakan pusat dari pengajaran bahasa serta bagian terpenting untuk peserta didik. Kosakata memiliki peran yang sangat penting untuk peserta didik dalam memperoleh bahasa. Penelitian telah menemukan bahwa pembaca dengan bahasa asing sebagai bahasa kedua menitik beratkan kemampuannya kepada pengetahuan akan kosakata bahasa asing, dan kurangnya pengetahuan akan hal tersebut adalah kendala utama dan terbesar untuk pembaca dengan bahasa kedua. Beberapa teknik dalam pengajaran kosakata bahasa asing adalah sebagai berikut (Alqahtani, 2015) : 1) Menggunakan obyek, 2) Menggambar, 3) Menggunakan ilustrasi dan gambar, 4) Kata yang kontras, 5) Enumerasi, 6) Mimik, ekspresi dan gerakan, 7) Menebak isi, 8) Pancingan, dan 9) Terjemahan.

Dijelaskan bahwa tahap atau langkah dalam pembelajaran berbahasa ada 4, yaitu (Israel, 2013) : 1) Phonology yang terdiri dari simbol-simbol yang merepresentasikan suara dari bahasa, 2) Morphology merupakan bentuk kata yang membangun makna dna fungsi tata bahasa, 3) Sintaks yaitu urutan kata yang merupakan formasi dai kalimat, dan 4) Semantik yaitu kosakata yang menciptakan pengertian dan pemahaman.

Dalam penggunaan bahasa pertama, seorang peserta didik bahasa kedua atau bahasa asing dituntut untuk tahu, paham, dan mampu menggunakan sistem bahasa target yang dipelajarinya dalam bentuk ketrampilan berbahasa (mendengar, berbicara, membaca dan menulis) dengan benar dan tepat seperti penutur asli (Saadah, 2016). Namun dikarenakan setiap akan belajar sesuatu yang baru, peserta didik tidak luput dari kendala dan kesulitan sehingga menyebabkan kesalahan dalam berbahasa. Sebagai seorang pendidik, guru pun perlu memikirkan selaku pembimbing yang bertanggung jawab mengarahkan mereka menuju penguasaan bahasa agar lebih baik.

Salah satu bentuk kesulitan atau kendala lain dalam pembelajaran berbahasa adalah kecemasan dalam pembelajaran berbahasa. Sudah banyak peneliti yang mengkaji mengenai masalah ini dikarenakan fenomena tersebut mempengaruhi peserta didik. Kecemasan berbahasa adalah tipe kecemasan yang berasosiasi khususnya pada pembelajaran bahasa kedua, dapat bersumber dari mana saja (Lucas, 2011). Horwitz (Lucas, 2011) menemukan bahwa kecemasan peserta didik dalam menggunakan bahasa asing dapat disebabkan oleh : Ketakutan dalam berkomunikasi dengan orang lain, kecemasan ketika akan melakukan tes, dan ketakutan akan hasil evaluasi yang negatif atau tidak bagus. Maka dari itu, strategi yang dibutuhkan oleh guru kepada peserta didik dalam mengatasi masalah yang tepat pada kecemasan berbahasa: 1) Strategi mendengarkan, 2) Strategi kosakata, 3) strategi berbicara, 4) Strategi membaca, 5) Strategi menulis, dan 6) Strategi menggunakan terjemahan.

Berdasarkan masalah atas kendala dan kesulitan yang sering dihadapi oleh peserta didik dalam pembelajaran berbahasa, seorang guru perlu menentukan strategi yang tepat dalam menyikapi masalah tersebut. Cara pertama dalam mengelompokkan strategi adalah dengan menggabungkan strategi pembelajaran bahasa dengan strategi penggunaan bahasa. Cara kedua adalah dengan bidang keterampilan, dalam pendekatan ini strategi dapat berperan dalam 
menentukan keterampilan mendengarkan, berbicara, membaca serta menulis. Sedangkan cara ketiga adalah menentukan fungsinya, yaitu metakognitif, kognitif, afektif dan sosial (Cohen, 2011).

\section{Pembelajaran Berbasis Lagu dalam Pembelajaran Berbahasa Asing}

Kosakata memiliki peranan yang penting dalam pembelajaran berbahasa. Kosakata dapat menuntun kepada komunikasi yang efektif, baik secara lisan maupun tulisan. Dengan strategi pengajaran dan pembelajaran yang cocok dan efektif, dapat memperkuat kemampuan peserta didik dalam kemampuan kosakata yang dimilikinya (Sohot, 2018). Apabila seorang individu ingin lancar dan fasih dalam berbahasa asing, individu tersebut perlu banyak memperoleh dan bagus dalam kosakata dikarenakan hubungan satu sama lain.

Dalam sebuah penelitian oleh Sohot (2018), strategi yang digunakan adalah menggunakan lagu aksi yang mengintegrasikan dalam bermain peran serta mengekpresikan katakata dan struktur bahasa. Lebih jauh, lagu aksi dapat membantu peserta didik mempelajari bahasa dan mengirimkan energi positif ke kelas. Peserta didik perlu membuat hubungan antara bahasa yang baru dipelajari serta pengertiannya dengan menghubungkan kosakata yang dibuat melalui gerakan. Sebuah lagu memiliki banyak sumber kosataka bagi peserta didik, struktur kalimat dan pola kalimat yang menjelaskan mengapa strategi ini menjadi salah satu strategi yang efektif dalam pengajaran berbahasa asing. Selain memperkuat kemampuan kosakata peserta didik, lagu juga dapat membantu peserta didik merendahkan filter afektif mereka dan lebih memiliki kepercayaan diri mereka dalam belajar pembelajaran berbahasa.

Pembelajaran di masa sekarang lebih mengedepankan kepada sebuah invasi dalam sebuah pembelajaran dengan adanya penggunaan media pembelajaran yang membuat peserta didik tertarik dalam belajar bahasa asing, dengan tambahan dapat meningkatkan pemahaman peserta didik mengenai materi kebahasaan. Menurut Gagne dan Briggs (Utomo, 2019), media pembelajaran merupakan alat yang digunakan untuk menyampaikan isi dari pembelajaran di dalam bentuk buku, modul, teks program, rekaman, kamera, perekam video, slide, foto, gambar, grafik, televisi, komputer dan lain-lain.

Hal terpenting dari penggunaan lagu pada penguatan kemampuan berbahasa adalah termasuk ritmik dan pengulangan sifat dan kegembiraan yang diasosiasikan dengan melodi dan isi yang mengantar kepada kegiatan pembelajaran (Ifadah \& Aimah, 2012; Sevik, 2012; Sophya, 2013). Kebanyakan sekolah dasar menggunakan lagu sebagai sebagai teknik dalam mengajar, dan Cameron (Sevik, 2012) mengklaim bahwa penggunaan lagu dan rima sangat penting dalam pembelajaran berbahasa asing di kelas. Cullen (Sevik, 2012) memaparkan bahwa lagu penting sebagai alat pengajaran berbahasa asing dikarenakan kebanyakan guru menemukan bahwa peserta didik senang mendengarkan musik dalam kelas berbahasa serta memiliki pandangan yang kuat dalam hal musik. Persamaan dengan musik menjadikan lagu sebagai alat penting dalam menciptakan suasana kelas yang aman dan alamiah dalam menghadapi sifat malu dan raguragu dari sebagian diri peserta didik. Lagu juga menyediakan kesempatan yang bagus dalam repetisi dan praktik yang sekiranya akan terasa membosankan. Selain itu juga, lagu memberikan kejadian dalam penggunaan bahasa itu menyenangkan dan dapat dinikmati.

Penelitian telah dilakukan dalam mengkaji kegunaan lagu dalam pengajaran kosakata, dikarenkan kosakata merupakan pusat terpenting dalam pembelajaran berbahasa terutama bahasa asing (Kayyis, 2015). Isi dari lagu itu tidak hanya untuk menghibur peserta didik, namun juga menawarkan cara yang baru dalam melakukan pembelajaran berbahasa. Lozanov (Kayyis, 2015) menyatatakn bahwa atmosfer yang diciptakan dari lagu menguatkan kemampuan dalam mengingat kosakata baru. Hal ini dikarenakan orang-orang merasa bahwa bahwa lebih mudah mengingat sesuatu yang menyenangkan dan memiliki nada daripada kalimat yang normal dan biasa-biasa saja. Terutama, lagu dapat membantu memperoleh 
perhatian serta konsentrasi peserta didik Brewer (Kayyis, 2015).

Lagu juga mengandung beberapa elemen di dalam bahasa yang digunakan sehari-hari dalam komunikasi, seperti banyaknya ragam kosakata baru, tata bahasa, aksen yang luas serta aspek kebudayaan yang dikenalkan secara alamiah. Siskova (Kayyis, 2015; Phisutthangkoon \& Panich, 2016) juga memaparkan hal yang serupa, bahwa lagu dapat digunakan dalam memahami dan menciptakan bahasa, mengingat kata-kata seiring berjalannya waktu sehingga mudah diingat, serta merupakan pengembangan dari strategi yang mengatasi jarak di antara kata pengetahuan, termasuk mengatasi kata-kata yang tidak diketahui.

\section{Hasil Telaah}

Media pembelajaran merupakan perantara yang digunakan oleh guru dengan murid untuk memudahkan terciptanya proses pembelajaran. Salah satu bentuk media yang umum ditemukan adalah media audio. Dalam pembelajaran berbahasa yang umumnya mengutamakan 4 keterampilan yaitu keterampilan mendengar, berbicara, membaca dan menulis.

Bentuk media audio seperti lagu dapat membuat peserta didik menguasai dua dari empat keterampilan tersebut, yaitu keterampilan mendengar dan keterampilan berbicara. Iringan kosakata asing dengan melodi yang mudah untuk dihafal akan membuat kosakata tersebut terbayang-bayang dalam pikiran peserta didik. Apabila peserta didik terutama berusia dini didengarkan audio yang memiliki melodi seperti lagu, tentu kata-kata yang terkandung dalam lagu tersebut lebih cepat diserap daripada hanya didengarkan kata-kata bahasa asing dengan nada yang monoton. Terutama jika guru menggunakan melodi yang mudah diingat seperti lagu pop yang tren di kalangan peserta didik.

Jika lagu yang diputar oleh guru merupakan lagu yang digemari oleh peserta didik untuk didengarkan maka kemampuan mendengar peserta didik akan meningkat seiring dengan motivasinya dalam belajar bahasa asing. Jika peserta didik mendengarkan berulang-ulang beberapa lagu yang mudah diingat akan terbayang kosakata-kosakata asing yang selalu digumamkan oleh peserta didik. Dari sinilah jika dikembangkan terus-menerus, maka keterampilan berbicara peserta didik juga akan meningkat dan dikuasai dengan mengenal lagu bahasa asing.

Tidak hanya itu saja, tentunya dengan menggunakan media lagu pada pembelajaran akan meningkatkan motivasi dan suasana belajar peserta didik. Jika peserta didik hanya mendengarkan penjelasan guru pada pembelajaran berbahasa asing, maka tentunya peserta didik akan merasa bosan dan tidak termotivasi. Berbeda jika menggunakan media lagu yang memiliki irama dan tempo cepat sehingga peserta didik pun juga akan merasa semangat dan termotivasi dalam belajar.

Berdasarkan beberapa hasil penelitian yang telah dipaparkan, pembelajaran berbasis lagu banyak digunakan oleh guru-guru dalam mata pelajaran yang bervarian. Maka dapat diartikan bahwa pendidik tidak jarang menggunakan lagu sebagai media dalam pembelajaran apapun. Hal tersebut dapat dibuktikan berdasarkan data grafik Google Trends untuk Song Based Learning dalam jangka waktu 10 tahun terakhir di seluruh dunia pada gambar berikut ini: 


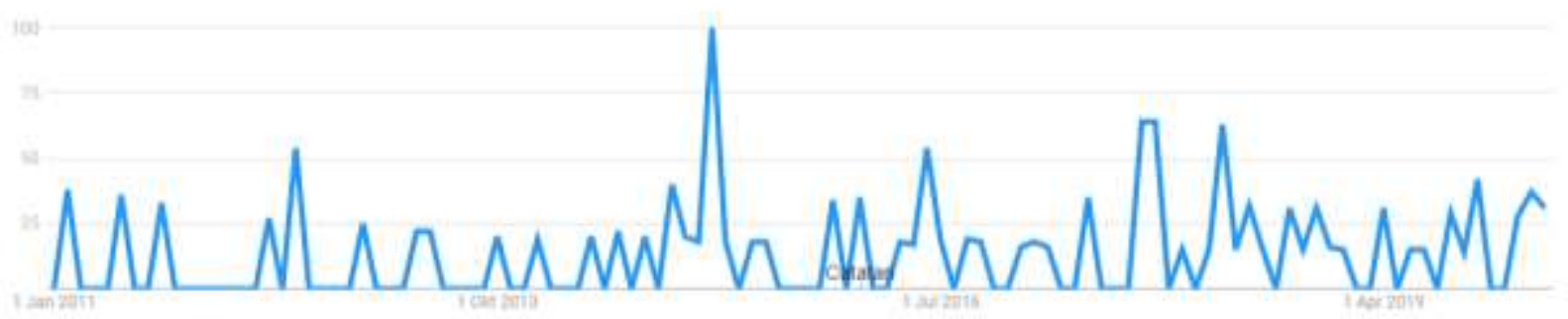

Gambar 2. Grafik Tren Pencarian Song Based Learning pada Google Trends selama 10 Tahun Terakhir di Seluruh Dunia

(sumber : https://trends.google.com/trends/explore?date=2011-01-01\%202020-05-

$07 \& \mathrm{q}=$ song $\% 20$ based $\% 20$ learning)

Berdasarkan gambar grafik di atas, dapat dilihat bahwa tren pencarian Song Based Learning mengalami penaikan dan penurunan yang tidak stabil. Namun, jika ditelusuri, Amerika Serikat merupakan wilayah terbanyak yang melakukan pecarian song based learning pada penelusuran website. Hal tersebut dipetakan pada gambar di bawah ini:

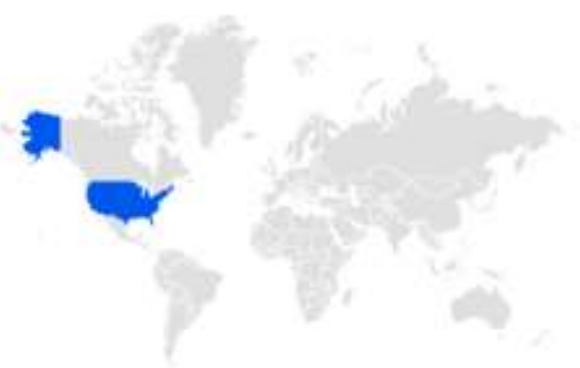

Gambar 3. Pemetaan Penggunaan Song Based Learning Terbanyak di Amerika Serikat pada Google Trends

(sumber : https://trends.google.com/trends/explore?date=2011-01-01\%202020-05-07\&q=song\%20based\%20learning)

Sehingga, jika penelusuran dipersempit ke wilayah Amerika Serikat, maka bentuk grafik pencarian song based learning akan berubah seperti gambar di bawah ini: 


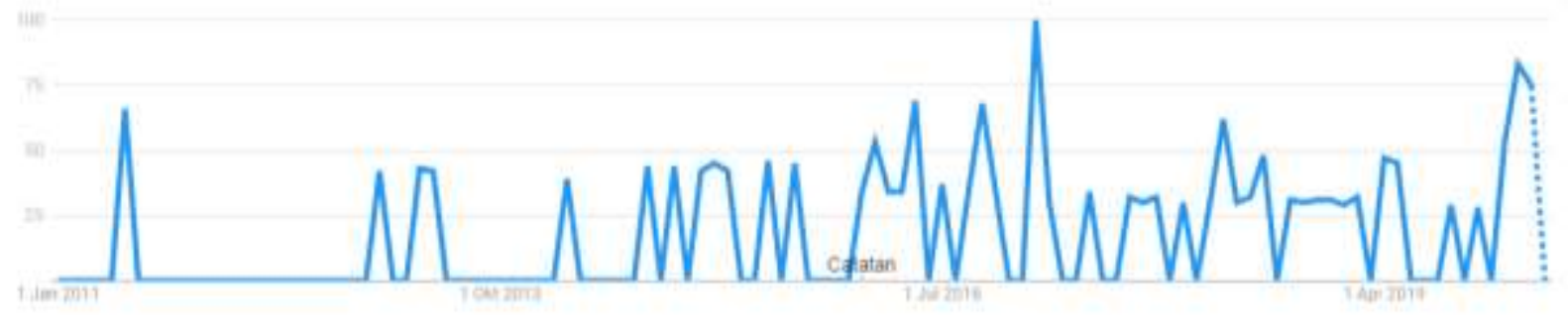

Gambar 4. Grafik Tren Pencarian Song Based Learning pada Google Trends selama 10 Tahun Terakhir di Amerika Serikat

(sumber : https://trends.google.com/trends/explore?date=2011-01-01\%202020-05-

$07 \&$ geo=US\&q=song $\% 20$ based $\% 20$ learning)

Berdasarkan gambar grafik di atas dapat disimpulkan seiring berjalannya waktu, pembelajaran berbasis lagu masih menjadi pencarian masyarakat terutama wilayah Amerika Serikat. Bahkan, jika dicermati dengan baik, penurunan yang terjadi sejak pertengahan tahun 2016 tidak terlalu drastis seperti tahun-tahun sebelumnya. Dan jika dicermati lebih dalam, jumlah penelusuran websites tren media lagu dalam pembelajaran selama empat tahun terakhir lebih banyak jika dibandingkan dengan tahuntahun sbeelumnya. Hal ini membuktikan bahwa pembelajaran yang menggunakan lagu masih diminati oleh masyarakat bahkan sampai saat ini. Penggunaan lagu dalam pembelajaran pun masih populer sebagai media pembelajaran bahkan akhir-akhir ini yang seharusnya teknologi lebih dimajukan dan diminati oleh masyarakat.

Jika dibandingkan dengan Amerika Serikat, penelusuran websites media pembelajaran lagu di Google di negara Indonesia mengalami penurunan seiring berjalannya tahun. Pencarian paling banyak terjadi pada akhir tahun 2011 dengan kenaikan yang lumayan tajam. Namun sejak pada akhir tahun 2015, pencarian tersebut semakin menurun dan tidak ada kenaikan yang begitu tajam dibandingkan dengan Amerika Serikat. Penggambaran lebih lanjut mengenai grafik seperti pada gambar di bawah ini:

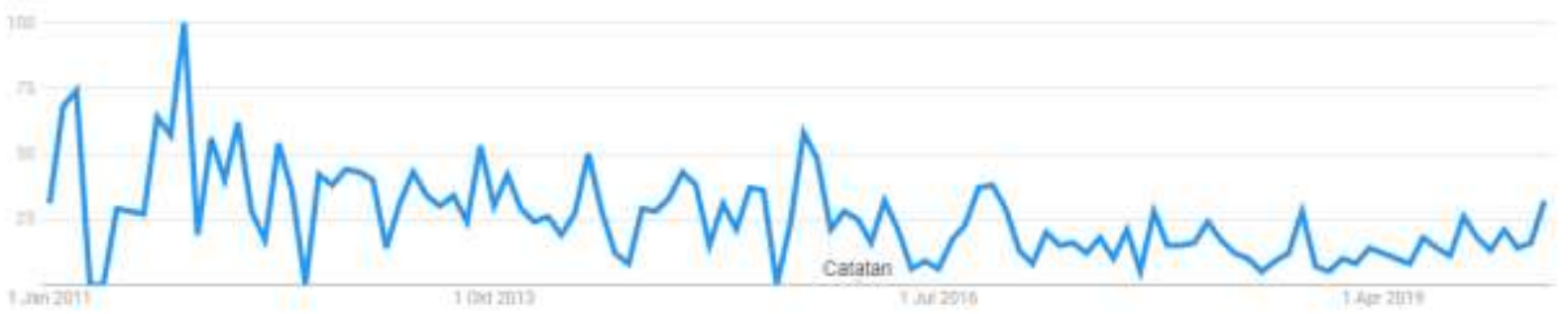

Gambar 5. Grafik Tren Pencarian Song Based Learning pada Google Trends selama 10 Tahun Terakhir di Indonesia

(sumber : https://trends.google.com/trends/explore?date=2011-01-01\%202020-05-

07\&geo=ID\&q=media\%20pembelajaran\%20lagu) 
Namun, sama seperti di cakupan wilayan seluruh dunia maupun Amerika Serikat, sampai saat ini, penelusuran web mengenai media pembelajaran lagu di Indonesia masih terhitung lumayan banyak, walaupun tidak sebanyak tahuntahun sebelumnya. Dengan itu membuktikan, bahwa media pembelajaran lagu masih diminati oleh masyarakat baik di seluruh dunia, Amerika Serikat, maupun Indonesia.

\section{SIMPULAN DAN REKOMENDASI}

Media dalam pendidikan adalah sebuah instrumen yang berpengaruh dalam menentukan keberhasilan dari proses belajar mengajar. Memanfaatkan media pembelajaran dapat meningkatkan motivasi belajar, minat dan keinginan dalam belajar peserta didik. Salah satu media pembelajaran yang tepat dalam pembelajaran berbahasa asing adalah lagu. Hal terpenting dari penggunaan lagu pada penguatan kemampuan berbahasa adalah termasuk ritmik dan pengulangan sifat dan kegembiraan yang diasosiasikan dengan melodi dan isi yang mengantar kepada kegiatan pembelajaran. Maka dengan digunakannya media lagu dalam pembelajaran berbahasa asing, peserta didik dapat termotivasi dan tertarik dalam mengikuti pembelajaran berbahasa, bukan hanya dapat meningkatkan keterampilan dasar berbahasa yang mencakup mendengarkan, berbicara, membaca dan menulis. Tren pencarian yang berhubungan mengenai penggunaan lagu dalam pembelajaran mengalami kenaikan dan penurunan yang signifikan, namun sampai saat ini masih menjadi suatu hal yang diminati oleh masyarakat.

Sedangkan untuk saran adalah sebaiknya guru-guru lebih baik menggunakan media yang sesuai dalam pembelajaran berbahasa terutama bahasa asing. Misalnya dengan menggunakan media lagu maka kemampuan berbahasa asing peserta didik akan meningkat dibandingkan dengan menggunakan metode drills saja.

\section{DAFTAR PUSTAKA}

ALQAHTANI, M. (2015). The importance of vocabulary in language learning and how to be taught. International Journal of
Teaching and Education, III(3), 21-34. https://doi.org/10.20472/te.2015.3.3.002

Arsyad, A. (2011). Media pembelajaran. Jakarta: PT Raja Grafindo Persada.

Atmaja, I. M. D. (2014). Ethnomatematika Pencipta Lagu dan Kaitannya dengan Materi Pembelajaran Matematika. Jurnal Santiaji Pendidikan (JSP), 4(1).

Aydoğan, H., \& Akbarov, A. A. (2014). The four basic language skills, whole language \& intergrated skill approach in mainstream university classrooms in Turkey. Mediterranean Journal of Social Sciences, 5(9), 672.

Bartolotti, J., \& Marian, V. (2012). Language Learning and Control in Monolinguals and Bilinguals. Cognitive Science, 36(6), 1129-1147. https://doi.org/10.1111/j.15516709.2012.01243.x

Cohen, A. D. (2011). Second language learner strategies. Handbook of Research in Second Language Teaching and Learning, 2(Part V), 681-698.

Coleman, R. C. (2017). Verbal Memory and Popular Song: Possible Applications for Language Teaching and Learning. 2(1975), 106-111.

Dufva, H., Suni, M., Aro, M., \& Salo, O.-P. (2011). Languages as objects of learning: language learning as a case of multilingualism. Apples - Journal of Applied Language Studies, 5(1), 109-124.

Falahudin, I. (2014). Pemanfaatan media dalam pembelajaran. Jurnal Lingkar Widyaiswara, 1(4), 104-117.

Gilakjani, A. P., \& Sabouri, N. B. (2016). Learners' Listening Comprehension Difficulties in English Language Learning: A Literature Review. English Language Teaching, 9(6), 123-133.

Ifadah, M., \& Aimah, S. (2012). Keefektifan Lagu Sebagai Media Belajar Dalam Pengajaran Pronounciation/Pengucapan. PROSIDING SEMINAR NASIONAL INTERNASIONAL, 1(1).

Israel, H. F. (2013). Language Learning Enhanced by Music and Song. Literacy Information 
and Computer Education Journal, Special 2(1), 1360-1366. https://doi.org/10.20533/licej.2040.2589.2 013.0180

Jazuly, A. (2016). Peran bahasa inggris pada anak usia dini. Jurnal Pendidikan Dompet Dhuafa, 6(01), 33-40.

Kayyis, R. (2015). Building Vocabulary Using Pop Songs. Jurnal SMART, 1(1), 32-42. Retrieved from http://ejournal.stkipmpringsewulpg.ac.id/index.php/smart

Keskin, F. (2011). Using songs as audio materials in teaching Turkish as a foreign language. Turkish Online Journal of Educational Technology, 10(4), 378-383.

Lestari, N. M. D., Suniasih, N. W., \& Darsana, I. W. (2017). PENGARUH MODEL PEMBELAJARAN SNOWBALL THROWING BERBASIS LAGU-LAGU ANAK TERHADAP KOMPETENSI PENGETAHUAN PKN. Journal of Education Technology, 1(3), 163-168.

Lucas, R. I. (2011). Philippine ESL Journal, Vol. 7, July 2011. Philippine ESL Journal, 7(July), 94-119.

Mahnun, N. (2012). Media pembelajaran (kajian terhadap langkah-langkah pemilihan media dan implementasinya dalam pembelajaran). An-Nida', 37(1), 27-34.

Miranti, I., Engliana, \& Hapsari, F. S. (2015). Penggunaan Media Lagu Anak-Anak Dalam Mengembangkan Kemampuan Kosakata Bahasa Inggris Siswa Di Paud. Jurnal Ilmiah Kependidikan, II(No. 2 Juli), 167-173.

Moeller, A. J., \& Catalano, T. (2015). Foreign Language Teaching and Learning. International Encyclopedia of the Social \& Behavioral Sciences: Second Edition, 327-332. https://doi.org/10.1016/B978-008-097086-8.92082-8

Nagauleng, A. M. (2015). Meningkatkan Kemampuan Siswa Dalam Berbahasa Inggris Dengan Menggunakan Lagu-lagu Berbahasa Inggris. Al-Riwayah: Jurnal Kependidikan, 7(2), 199-209.
Nurseto, T. (2011). Membuat media pembelajaran yang menarik. Jurnal Ekonomi Dan Pendidikan, 8(1).

Phisutthangkoon, K., \& Panich, M. (2016). Effectiveness of English Song Activities on Vocabulary Learning and Retention. The European Conference on Language Learning.

Printina, B. I. (2017). Strategi Pembelajaran Sejarah Berbasis Lagu-lagu Perjuangan dalam Konteks Kesadaran Nasionalisme. AGASTYA: JURNAL SEJARAH DAN PEMBELAJARANNYA, 7(01).

Ratminingsih, N. M. (2010). Pengaruh teknik pembelajaran dan tipe kepribadian terhadap keterampilan mendengarkan bahasa Inggris: Studi eksperimen pada siswa SD LAB Undiskha Singaraja. Disertasi Doktor.

Rukholm, V. N. (2015). Singing to speak: An examination of adult L2 learners and vocabulary learning through song. Italica, 92(1), 171-192.

Saadah, F. (2016). Analisis kesalahan berbahasa dan peranannya dalam pembelajaran bahasa asing. Wahana Akademika: Jurnal Studi Islam Dan Sosial, 14(1).

Sevik, M. (2012). Teaching Listening Skills to Young Learners through. English Teaching Forum, 50(3), 10-17. ERIC.

Sohot, M. B. (2018). Pupils 'Perceptions on the Use of Action Songs in Teaching and Learning Vocabulary. 4(6), 117-120.

Sophya, I. V. (2013). Pembelajaran Bahasa Inggris Melalui Lagu Pada Anak Usia Dini. Kudus: STAIN Kudus.

Subali, B., \& Handayani, L. (2012). Pengembangan CD Pembelajaran Lagu Anak Untuk Menumbuhkan Pemahaman SAINS Siswa Sekolah Dasar. Jurnal Pendidikan Fisika Indonesia, 8(1).

Utomo, J. I. (2019). The Effect of Songs as A Medium to Teach Recount Text for Listening Skills (Experimental Study of SMP Islam Terpadu PAPB Semarang in The Academic Year of 2018/2019). 188(Eltlt 2018), 161-164. https://doi.org/10.2991/eltlt-18.2019.56 